\title{
AMPLITUDES OF SURFACE WAVES AND MAGNITUDES OF SHALLOW EARTHQUAKES*
}

\author{
By B. GutenberG
}

Magnitudes were defined by Richter (1935) for earthquakes recorded at short distances. Determination of earthquake magnitudes on the same scale, using teleseismic records, is based on the amplitudes of the surface waves (GutenbergRichter, 1936). The fundamental equation for the calculation of the magnitude $M$ of teleseisms is

$$
M=\log A-\log B+C+D
$$

where $A=$ horizontal component of the maximum ground movement in microns $(0.001 \mathrm{~mm}$.) during surface waves having periods of about 20 seconds; $B=$ the same quantity for a shock of magnitude zero ( $B$ depends only on the distance of the station from the epicenter for a given focal depth; $\log B$ is always negative); $C$ is a constant for each station, correcting for the effects of special conditions of the ground near the station and of the instrumental equipment; and $D$ depends on the depth of focus, the original distribution of energy in azimuth, the absorption of the waves, and on the effect of irregularities along the wave path. For epicentral distances greater than about $20^{\circ}$, trace amplitudes $b$ (measured in $\mathrm{mm}$.) of the corresponding surface waves as recorded by standard Wood-Anderson torsion seismographs may be used; according to Gutenberg-Richter (1936, p. 122),

$$
\log b=\log B-2.5
$$

For distances less than $20^{\circ}$, equation (2) does not hold, as it is based on the supposition that the maximum trace amplitudes correspond to waves with periods of about 20 seconds, which is not fulfilled for distances less than $20^{\circ}$. No attempt has been made to find the values of $B$ in equation (1) for these distances, but instead the original tables given by Richter have been used in all instances of near-by shocks; these are based on the average maximum trace amplitudes recorded by two horizontal components of standard torsion seismographs regardless of the phase. After many careful discussions it was considered best to retain the use of the average trace amplitudes for the determination of the magnitude of near-by shocks and of the total horizontal amplitudes for teleseisms. The maximum difference in the resulting logarithm is 0.15 , but this is considered in the respective tables. All tables in the present paper are based on the total horizontal amplitudes. If only one component is available for the determination of the magnitude $M$, the total horizontal component must be estimated; usually, multiplication of the given amplitude by 1.4 gives the desired total within the limits of error.

In the previous investigation (Gutenberg-Richter, 1936) it was found that, approximately, $\log B=-5.0$ (or $\log b=-7.5$ ) for an epicentral distance $\Delta=90^{\circ}$, and observed values for other distances could be fitted into a curve giving $\log B$ (or $\log b$ ) as a function of the distance $\Delta$ (in degrees) for average conditions. In the present paper it was assumed that for $\Delta=90^{\circ}$ we have $\log B=-5.04$ corresponding to the best data available. This value controls the zero point for the magnitude scale, but does not affect the difference in calculated magnitudes for various shocks.

* Manuscript received for publication June 2, 1944. 
The maximum horizontal ground amplitudes $B$ of surface waves having periods of about 20 seconds at epicentral distances $\Delta$ greater than $20^{\circ}$ in a shock of magnitude zero should be given, theoretically, by

$$
-\log B=5.04+1 / 2[48.25 k(\Delta-90)+\log \sin \Delta+1 / 3(\log \Delta-1.954)]
$$

This corresponds to equation (2) in Gutenberg-Richter (1939, p. 103), taking $\Delta_{1}=90^{\circ} . \Delta$ is to be measured in degrees, $k$ is the absorption factor per $\mathrm{km}$. for surface waves with periods of about 20 seconds; $48.25=0.434 \times 111$. . The absolute value of the last term in equation (3) multiplied by the factor $1 / 2$ exceeds 0.1 only for distances less than $23^{\circ}$ or beyond $360^{\circ}$. ( $W_{3}$ and later waves).

For surface waves having periods of about 20 seconds the following values of $k$ (per $\mathrm{km}$.) have been found previously:

Continental paths................................. 0.00016

Around the earth or across the Pacific ................. 0.00030

Along the boundary of the Pacific Basin................ 0.0005

TABLE 1

Corrections $C$ to Be Added for Various Stations in the Calculation of Earthquake Magnitudes of Teleseisms

$(n=$ number of observations; $s=$ standard error of one observation; $e=$ standard error of $C$ )

\begin{tabular}{|c|c|c|c|c|c|c|c|c|c|}
\hline Station & $n$ & $s$ & $\varepsilon$ & $C$ & Station & $n$ & $s$ & $e$ & $C$ \\
\hline Agra & 20 & 0.4 & 0.08 & +0.06 & Lick. & 12 & 0.3 & 0.08 & +0.06 \\
\hline Baku. & 29 & 0.3 & 0.05 & -0.21 & Osaka..... & 29 & 0.3 & 0.06 & +0.01 \\
\hline Bombay & 21 & 0.2 & 0.05 & +0.30 & Ottawa... & 10 & 0.2 & 0.07 & -0.04 \\
\hline Calcutta. & 18 & 0.2 & 0.06 & +0.03 & Pasadena. & 32 & 0.3 & 0.05 & +0.05 \\
\hline Cartuja. & 40 & 0.2 & 0.03 & 0.00 & Perth.... & 9 & 0.2 & 0.07 & -0.21 \\
\hline Chiufeng. & 6 & 0.2 & 0.06 & -0.03 & Potsdam. & 20 & 0.2 & 0.04 & -0.04 \\
\hline De Bilt. & 40 & 0.2 & 0.04 & -0.17 & Pulkovo... & 92 & 0.2 & 0.02 & +0.04 \\
\hline Hamburg. & 95 & 0.2 & 0.02 & -0.23 & Riverview. . & 36 & 0.3 & 0.04 & +0.25 \\
\hline Helgoland. & 9 & 0.2 & 0.08 & -0.10 & Stuttgart & 24 & 0.2 & 0.03 & -0.08 \\
\hline Helwan... & 33 & 0.3 & 0.05 & +0.05 & Sverdlovsk. & 62 & 0.2 & 0.02 & +0.06 \\
\hline Irkutsk. & 21 & 0.3 & 0.06 & +0.13 & Tashkent & 42 & 0.3 & 0.04 & +0.14 \\
\hline Kew..... & 64 & 0.2 & 0.03 & -0.09 & Toledo... & 14 & 0.3 & 0.07 & +0.01 \\
\hline Koenigsberg & 17 & 0.2 & 0.06 & -0.04 & Uecle. & 34 & 0.2 & 0.03 & -0.04 \\
\hline Kucino.... & 75 & 0.2 & 0.02 & +0.05 & Upsala. . & 21 & 0.2 & 0.04 & +0.05 \\
\hline La Paz. & 61 & 0.3 & 0.04 & +0.10 & Vladivostok & 32 & 0.4 & 0.07 & +0.43 \\
\hline La Plata. & 10 & 0.3 & 0.10 & +0.41 & Zikawei.. & 10 & 0.2 & 0.08 & +0.27 \\
\hline Leipzig. . & 13 & 0.1 & 0.05 & -0.05 & & & & & \\
\hline Pasadena. & 43 & 0.2 & 0.04 & +0.08 & Riverside. & 41 & 0.3 & 0.04 & +0.05 \\
\hline Mount Wilson. & 43 & 0.2 & 0.03 & +0.06 & La Jolla.. & 40 & 0.2 & 0.03 & 0.00 \\
\hline Santa Barbara. & 41 & 0.3 & 0.05 & -0.09 & Haiwee. & 41 & 0.2 & 0.03 & +0.08 \\
\hline Tinemaha... & 43 & 0.2 & 0.04 & +0.12 & & & & & \\
\hline
\end{tabular}

In the course of recent investigations the author determined magnitudes for several hundred earthquakes, using equation (1) with the values of $b$ (or the corresponding $B$, equation 2 ) given in figure 6 of the previous paper and neglecting the terms $C$ and $D$. The results indicate that the calculated magnitude $M$ was above 
average at certain stations, below at others. This suggests that for the first group the station constant $C$ is negative and for the second group positive. Supposing that the errors in $B$ cancel on the average for various distances and that the average of $D$ in the instances used is zero, the value of $C$ for each station can be found. Results are given in the first part of table 1 ; the second part (for stations in southern California) will be discussed later in this paper. The standard errors $s$ and $e$ depend on the accuracy in reading the amplitudes, on combinations of circumstances (such as resonance phenomena and interference of waves) such as to produce one exceptionally large maximum, and on errors in $B$ and the effect of $D$. The values of $C$ are given to two decimals (although only the first is certain for most stations) in order to avoid the accumulation of errors in rounding off. Table 1 refers to surface waves having periods of about 20 seconds. The values of $C$ may be different for other waves, and for the Pasadena group of stations they certainly differ from those found for the short period waves in near-by earthquakes.

The "ground factors" $F$ given in earlier papers by various authors (summary in Gutenberg, 1932, p. 259) should be connected with $C$ by the equation $\log F=-C$. The following stations of table 1 were included in the earlier research:

$$
\begin{array}{cccccc} 
& \text { De Bilt } & \text { Hamburg } & \text { Potsdam } & \text { Pulkovo } & \text { Upsala } \\
\log F \text { (old) } \ldots \ldots \ldots \ldots \ldots & 0.0 & 0.2 & -0.1 & 0.0 & -0.2 \\
-C \text { (table 1) } \ldots \ldots \ldots \ldots & 0.2 & 0.2 & 0.0 & 0.0 & -0.1
\end{array}
$$

The finding of the earlier papers that $\log F$ is usually positive ( $C$ negative) for stations on sandy, water-saturated ground still holds. Differences between the earlier and the later data are probably due mainly to changes in the instruments used.

\section{TABLE 2}

Mean Deviations $d$ of Individual Values of $M$ from Averages for Various Distances ( $d$ is given in $1 / 100$ units of $M$; distances $\Delta$ are in degrees; $n=$ number of observations)

\begin{tabular}{|c|c|c|c|c|c|c|c|c|c|c|c|}
\hline$\Delta$ & $d$ & $n$ & $\begin{array}{l}-\log B \\
\text { calc. }\end{array}$ & $\Delta$ & $d$ & $n$ & $\begin{array}{c}-\log B \\
\text { calc. }\end{array}$ & $\Delta$ & $d$ & $n$ & $\begin{array}{c}-\log B \\
\text { calc. }\end{array}$ \\
\hline $13-18$ & -30 & 7 & 3.9 & 58,59 & +8 & 8 & 4.7 & 96,97 & -11 & 20 & 5.2 \\
\hline $19-21$ & -11 & 7 & 3.9 & 60,61 & +3 & 21 & 4.8 & 98,99 & +7 & 12 & 5.0 \\
\hline 22,23 & -17 & 3 & 4.0 & 62,63 & -1 & 24 & 4.8 & 100,101 & +8 & 36 & 5.05 \\
\hline 24,25 & -35 & 4 & 4.25 & 64,65 & -2 & 23 & 4.8 & 102,103 & -9 & 13 & 5.25 \\
\hline 26,27 & -10 & 3 & 4.1 & 66,67 & -3 & 10 & 4.9 & 104,105 & +1 & 19 & 5.15 \\
\hline 28,29 & -5 & 10 & 4.1 & 68,69 & 0 & 24 & 4.9 & 106,107 & +11 & 10 & 5.05 \\
\hline 30,31 & -29 & 10 & 4.4 & 70,71 & -4 & 48 & 4.95 & 108,109 & +5 & 13 & 5.15 \\
\hline $32-35$ & +1 & 7 & 4.2 & 72,73 & -7 & 34 & 4.95 & 110,111 & -3 & 15 & 5.25 \\
\hline 36,37 & -10 & 14 & 4.4 & 74,75 & 0 & 29 & 4.9 & 112,113 & +6 & 5 & 5.15 \\
\hline 38,39 & -20 & 10 & 4.55 & 76,77 & +2 & 26 & 4.95 & 114,115 & -4 & 7 & 5.25 \\
\hline 40,41 & -8 & 12 & 4.5 & 78,79 & +7 & 34 & 4.95 & 116,117 & -2 & 9 & 5.3 \\
\hline 42,43 & -21 & 9 & 4.65 & 80,81 & -2 & 42 & 5.0 & 118,119 & -8 & 6 & 5.35 \\
\hline 44,45 & -10 & 16 & 4.6 & 82,83 & +1 & 22 & 5.0 & $120-125$ & +1 & 45 & 5.3 \\
\hline 46,47 & -10 & 8 & 4.65 & 84,85 & +1 & 54 & 5.0 & $126-130$ & +3 & 23 & 5.3 \\
\hline 48,49 & -2 & 16 & 4.6 & 86,87 & +3 & 27 & 5.0 & $131-140$ & +13 & 41 & 5.3 \\
\hline 50,51 & +4 & 16 & 4.6 & 88,89 & +3 & 20 & 5.0 & $141-150$ & +5 & 32 & 5.35 \\
\hline 52,53 & +3 & 10 & 4.7 & 90,91 & +8 & 30 & 5.0 & $151-160$ & +13 & 15 & 5.25 \\
\hline 54,55 & -1 & 22 & 4.7 & 92,93 & +7 & 21 & 5.0 & $161-170$ & +4 & 12 & 5.35 \\
\hline 56,57 & +14 & 14 & 4.6 & 94,95 & -1 & 20 & 5.1 & $>175$ & +27 & 3 & 5.15 \\
\hline
\end{tabular}


Using the values of $C$ (table 1 ) but still supposing that $D=0$, equation (1) was used to redetermine $M$ for each shock and the deviations of the individual calculated values of $M$ from the corresponding average. It was assumed that these residuals are due to errors in the assumed value of $B$ as a function of distance. The average deviations for groups of distances are given in table 2 . They are relatively small and prevailingly negative for $\Delta$ less than $50^{\circ}$, positive for $\Delta$ greater than $125^{\circ}$. In adding these deviations to the assumed values of $\log B$ (based on the values of $b=A_{0}$ in figure 6, Gutenberg-Richter, 1936, p. 120), new values for $\log B$ were calculated (fourth column in table 2). A plot of the new values against the logarithm of the distance $\Delta$ gave practically a straight line between $\Delta=15^{\circ}$ and $130^{\circ}$. Consequently, a corresponding form was assumed for the application of the method of least squares between the limits of $\Delta$ given with the result

$$
-\log B=1.818+1.656 \log \Delta \quad \text { (for } \Delta \text { between } 15^{\circ} \text { and } 130^{\circ} \text { ) }
$$

Values of $\log B$ from (4) should be compared with the observations and the values found from equation (3). Characteristic results are given in table 3 . It was assumed

TABLE 3

Values of - $\log B$ from Table 2 (Observed), Equation (3) (Theory), and Equation (4) (EMPIRICAL FOR $\triangle$ BETWEEN $15^{\circ}$ AND $130^{\circ}$ )

\begin{tabular}{|c|c|c|c|c|c|c|c|c|c|c|c|c|}
\hline \multirow[b]{2}{*}{$-\log B$} & \multicolumn{12}{|c|}{$\Delta$ degrees } \\
\hline & 15 & 20 & 30 & 40 & 60 & 80 & 100 & 120 & 140 & 160 & 170 & 175 \\
\hline Observed. & $(3.9)$ & 3.9 & $(4.3)$ & 4.5 & 4.8 & 5.0 & 5.1 & 5.3 & 5.3 & 5.3 & 5.3 & 5.2 \\
\hline Equation (3) & 4.07 & 4.19 & 4.37 & 4.52 & 4.76 & 4.96 & 5.12 & 5.24 & 5.34 & 5.35 & 5.26 & 5.13 \\
\hline Equation (4) & 3.77 & 3.97 & 4.26 & 4.47 & 4.75 & 4.97 & 5.13 & 5.26 & $(5.37)$ & $(5.47)$ & $(5.51)$ & $(5.53)$ \\
\hline
\end{tabular}

that in $(3) k=0.0003$. For distances less than $30^{\circ}$ the observed values are slightly smaller than those calculated from (3). This may indicate that the surface waves are not fully developed at shorter distances. Between $\Delta=40^{\circ}$ and $140^{\circ}$ the agreement is better than should be expected when the errors involved, including the assumption of $k=0.0003$ without regard to wave path, are considered. Between the same limits, the empirical equation (4) gives values which agree with those of the theoretical equation (3) within \pm 0.05 . For distances greater than $140^{\circ}$ the observed values do not increase as indicated by the extrapolation given by equation (4), but agree with the values given by (3).

Table 4 contains the values of $-\log B$ which were finally adopted. Like those for $C$, they are given with two decimals to avoid accumulation of rounding-off errors. For distances less than $20^{\circ}$ values for $-\log b$ are given in table 5 as they are used in connection with shocks in California recorded by standard torsion seismographs as previously described. For distances greater than $20^{\circ}$ the numerical values of $-\log B$ in table 4 should be increased by 2.5 to give the corresponding $-\log b$.

The determination of the last quantity in (1), $D$, offers the most difficulty. It is influenced by the depth of focus. The values of $\log B$ in table 4 form a system of figures which are well established relative to each other, but their zero point is less 
certain. They were correlated with the original magnitude scale for California by using amplitudes of surface waves of shocks in California, Nevada, and Montana, recorded at stations about $90^{\circ}$ distant, while the magnitudes of these shocks were found from torsion-seismograph records of the near-by stations of the Pasadena and Berkeley groups. Thus, the absolute values of the new tables are affected by the

TABLE 4

Revised Values of $-\log B$ in Equation (1)

$(\Delta=$ epicentral distance in degrees)

\begin{tabular}{|c|c|c|c|c|c|c|c|c|c|c|c|}
\hline$\Delta$ & 0 & 1 & 2 & 3 & 4 & 5 & \multicolumn{2}{|c|}{6} & 7 & 8 & 9 \\
\hline 20 & 3.97 & 4.01 & 4.04 & 4.07 & 4.10 & \multicolumn{2}{|c|}{4.13} & 4.16 & 4.19 & 4.21 & 4.24 \\
\hline 30 & 4.26 & 4.29 & 4.31 & 4.33 & 4.35 & \multicolumn{2}{|c|}{4.38} & 4.40 & 4.41 & 4.43 & 4.45 \\
\hline 40 & 4.47 & 4.49 & 4.50 & 4.52 & 4.54 & \multicolumn{2}{|c|}{4.56} & 4.57 & 4.59 & 4.60 & 4.62 \\
\hline 50 & 4.63 & 4.65 & 4.66 & 4.67 & 4.69 & \multicolumn{2}{|c|}{4.70} & 4.71 & 4.73 & 4.74 & 4.75 \\
\hline 60 & 4.76 & 4.77 & 4.79 & 4.80 & 4.81 & \multicolumn{2}{|c|}{$\begin{array}{l}4.82 \\
4.92\end{array}$} & 4.83 & 4.84 & 4.85 & 4.86 \\
\hline 70 & 4.87 & 4.88 & 4.89 & 4.90 & 4.91 & & & & 4.94 & 4.95 & 4.93 \\
\hline 80 & 4.97 & 4.98 & 4.99 & 5.00 & 5.00 & \multicolumn{2}{|c|}{5.01} & 5.02 & 5.03 & 5.04 & 5.04 \\
\hline 90 & 5.05 & 5.06 & 5.07 & 5.08 & 5.09 & \multicolumn{2}{|c|}{5.09} & 5.10 & 5.11 & 5.12 & 5.12 \\
\hline 100 & 5.13 & 5.14 & 5.14 & 5.15 & 5.16 & \multicolumn{2}{|c|}{5.17} & 5.17 & 5.18 & 5.19 & 5.19 \\
\hline 110 & 5.20 & 5.21 & 5.21 & 5.22 & 5.22 & & & & 5.24 & 5.25 & 5.25 \\
\hline \multirow{2}{*}{\multicolumn{2}{|c|}{$\begin{array}{l}\Delta \ldots \ldots \ldots \ldots \\
-\log B \ldots \ldots \ldots\end{array}$}} & 124 & 128 & 130 & 135 & 140 & \multirow{2}{*}{$\begin{array}{l}145 \\
5.34\end{array}$} & \multirow{2}{*}{$\begin{array}{c}150 \\
5.35\end{array}$} & 160 & 162 & 165 \\
\hline & & 5.28 & 5.29 & 5.30 & 5.32 & 5.33 & & & 5.35 & 5.34 & 5.33 \\
\hline \multirow{2}{*}{\multicolumn{2}{|c|}{$\begin{array}{l}\Delta \ldots \ldots \\
-\log B\end{array}$}} & 170 & 172 & 173 & 174 & 175 & 176 & 177 & 178 & 179 & 180 \\
\hline & & 5.32 & 5.31 & 5.30 & 5.28 & 5.25 & 5.22 & 5.20 & 5.15 & 5.1 & 5.0 \\
\hline
\end{tabular}

TABLE 5

VALUES OF $-\log b$

\begin{tabular}{c|c|c|c|c|c|c|c|c|c}
\hline \hline$\ldots \ldots \ldots \ldots$ & 4 & $41 / 2$ & 5 & $51 / 2$ & 6 & $61 / 2$ & 7 & $71 / 2$ & 8 \\
$-\log b \ldots \ldots \ldots$ & 4.60 & 4.74 & 4.87 & 5.00 & 5.12 & 5.23 & 5.33 & 5.43 & 5.52 \\
\hline$\Delta \ldots \ldots \ldots \ldots$ & $81 / 2$ & 9 & $91 / 2$ & 10 & $101 / 2$ & 11 & $11 \frac{1 / 2}{12}$ & 12 & $121 / 2$ \\
$-\log b \ldots \ldots$ & 5.60 & 5.67 & 5.74 & 5.80 & 5.85 & 5.90 & 5.95 & 6.00 & 6.04 \\
\hline$\Delta \ldots \ldots \ldots \ldots$ & 13 & $131 / 2$ & 14 & 15 & 16 & 17 & 18 & 19 & 20 \\
$-\log b \ldots \ldots$ & 6.08 & 6.12 & 6.15 & 6.22 & 6.28 & 6.33 & 6.38 & 6.43 & 6.47 \\
\hline
\end{tabular}

unknown error of the correlation just mentioned as well as by the depth of focus of the shocks used. As foci in California are usually shallower than in most other regions, and the depth of focus of the Nevada and Montana shocks is known only approximately, no close value of the average focal depth to which table 4 corresponds can be given. It is probably between 20 and $25 \mathrm{~km}$. If table 4 is applied to a shock of greater focal depth, the resulting magnitude is too small. The difference depends on the change of velocity with depth in the focal area. In the case of a region with a layered crust, the decrease in the amplitudes of the surface waves with increasing 


\section{TABLE 6}

Deviations of Calculated Magnttudes for Southern California Stations from Average (Deviations are given in $1 / 10$ units of $M ; \Delta=$ average epicentral distance in degrees; stations are indicated by their first letter-list at end of table 1)

\begin{tabular}{|c|c|c|c|c|c|c|c|c|c|c|c|c|}
\hline \multirow[b]{2}{*}{ No. } & \multirow[b]{2}{*}{ Date } & \multirow[b]{2}{*}{ Epicenter region } & \multirow[b]{2}{*}{$M$} & \multirow[b]{2}{*}{$\Delta$} & \multicolumn{8}{|c|}{ Deviation } \\
\hline & & & & & $P$ & $M$ & $R$ & $L$ & $s$ & $H$ & $T$ & Mean \\
\hline $\begin{array}{l}1 \\
2 \\
3 \\
4 \\
5\end{array}$ & $\begin{array}{l}\text { 1939, Dec. } 26 \\
\text { 1942, Dec. } 20 \\
\text { 1941, June } 18 \\
\text { 1941, Nov. } 25 \\
\text { 1938, May } 8\end{array}$ & $\begin{array}{l}\text { Turkey...... } \\
\text { Turkey...... } \\
\text { N. Atlantic.. } \\
\text { Off Portugal. } \\
\text { Azores....... }\end{array}$ & $\begin{array}{l}7.9 \\
7.3 \\
6.3 \\
8.2 \\
6.6\end{array}$ & $\begin{array}{r}106 \\
105 \\
60 \\
76 \\
73\end{array}$ & $\begin{array}{r}+3 \\
-2 \\
0 \\
+2 \\
+2\end{array}$ & $\begin{array}{r}+3 \\
0 \\
+2 \\
+2 \\
+2\end{array}$ & $\begin{array}{r}? \\
-1 \\
0 \\
+2 \\
+2\end{array}$ & $\begin{array}{r}+3 \\
? \\
0 \\
+2 \\
+4\end{array}$ & $\begin{array}{r}+2 \\
? \\
-1 \\
-1 \\
+6\end{array}$ & $\begin{array}{r}+4 \\
0 \\
0 \\
0 \\
+3\end{array}$ & $\begin{array}{r}+2 \\
0 \\
+1 \\
+1 \\
+4\end{array}$ & $\begin{array}{r}+3 \\
0 \\
0 \\
+1 \\
+3\end{array}$ \\
\hline $\begin{array}{r}6 \\
7 \\
8 \\
9 \\
10\end{array}$ & $\begin{array}{lr}\text { 1941, Dec. } & 5 \\
\text { 1941, Dec. } & 6 \\
\text { 1939, Dec. } & 21 \\
\text { 1942, Aug. } & 6 \\
\text { 1939, Dee. } & 5\end{array}$ & $\begin{array}{l}\text { Costa Rica. } \\
\text { Costa Rica. } \\
\text { Costa Rica. } \\
\text { Guatemala.. } \\
\text { Guatemala.. }\end{array}$ & $\begin{array}{l}7.6 \\
7.0 \\
7.3 \\
7.6 \\
6.6\end{array}$ & $\begin{array}{l}41 \\
41 \\
40 \\
32 \\
31\end{array}$ & $\begin{array}{l}+1 \\
-2 \\
-2 \\
-1 \\
+4\end{array}$ & $\begin{array}{r}-1 \\
-3 \\
-2 \\
0 \\
+3\end{array}$ & $\begin{array}{r}0 \\
-5 \\
-2 \\
0 \\
+2\end{array}$ & $\begin{array}{l}+1 \\
-3 \\
-4 \\
-1 \\
+2\end{array}$ & $\begin{array}{r}0 \\
-3 \\
-2 \\
0 \\
+3\end{array}$ & $\begin{array}{r}0 \\
-4 \\
-2 \\
+3 \\
+2\end{array}$ & $\begin{array}{l}+1 \\
-3 \\
-2 \\
+4 \\
+3\end{array}$ & $\begin{array}{r}0 \\
-3 \\
-2 \\
+1 \\
+3\end{array}$ \\
\hline $\begin{array}{l}11 \\
12 \\
13 \\
14 \\
15\end{array}$ & $\begin{array}{l}\text { 1937, Dec. } 23 \\
\text { 1943, Feb. } 22 \\
\text { 1941, Apr. } 15 \\
\text { 1942, May } 14 \\
\text { 1940, May } 24\end{array}$ & $\begin{array}{l}\text { Ecuador.... } \\
\text { Peru....... }\end{array}$ & $\begin{array}{l}7.5 \\
7.5 \\
7.7 \\
8.1 \\
7.9\end{array}$ & $\begin{array}{l}25 \\
23 \\
20 \\
48 \\
59\end{array}$ & $\begin{array}{l}+5 \\
+1 \\
-3 \\
-5 \\
-6\end{array}$ & $\begin{array}{r}+2 \\
0 \\
-3 \\
-4 \\
-5\end{array}$ & $\begin{array}{l}+6 \\
+2 \\
-1 \\
-6 \\
-5\end{array}$ & $\begin{array}{r}+4 \\
0 \\
-4 \\
-6 \\
-4\end{array}$ & $\begin{array}{r}+5 \\
0 \\
-1 \\
-8 \\
-6\end{array}$ & $\begin{array}{r}+4 \\
? \\
-1 \\
-6 \\
-5\end{array}$ & $\begin{array}{r}+3 \\
+3 \\
0 \\
-5 \\
-5\end{array}$ & $\begin{array}{l}+4 \\
+1 \\
-2 \\
-6 \\
-5\end{array}$ \\
\hline $\begin{array}{l}16 \\
17 \\
18 \\
19 \\
20\end{array}$ & $\begin{array}{l}\text { 1942, Aug. } 24 \\
\text { 1942, Nov. } 10 \\
\text { 1943, Apr. } 16 \\
\text { 1939, Jan. } 25 \\
\text { 1942, June } 24\end{array}$ & $\begin{array}{l}\text { Peru..... } \\
\text { Off S.E. Africa } \\
\text { Chile......... } \\
\text { Chile...... } \\
\text { New Zealand. }\end{array}$ & $\begin{array}{l}8.2 \\
7.7 \\
8.0 \\
7.8 \\
7.1\end{array}$ & $\begin{array}{r}63 \\
153 \\
79 \\
82 \\
96\end{array}$ & $\begin{array}{l}-4 \\
+4 \\
+1 \\
-1 \\
-2\end{array}$ & $\begin{array}{r}-6 \\
+4 \\
+1 \\
0 \\
-2\end{array}$ & $\begin{array}{r}-6 \\
+2 \\
0 \\
-1 \\
-5\end{array}$ & $\begin{array}{r}-6 \\
? \\
-1 \\
0 \\
-3\end{array}$ & $\begin{array}{l}-8 \\
+4 \\
-1 \\
-1 \\
-4\end{array}$ & $\begin{array}{l}-5 \\
+2 \\
+1 \\
-1 \\
-4\end{array}$ & $\begin{array}{r}-4 \\
+3 \\
0 \\
0 \\
-4\end{array}$ & $\begin{array}{r}-5 \\
+3 \\
0 \\
-1 \\
-3\end{array}$ \\
\hline $\begin{array}{l}21 \\
22 \\
23 \\
24 \\
25\end{array}$ & $\begin{array}{lr}\text { 1941, Sept. } 16 \\
\text { 1941, Aug. } 2 \\
1942, \text { Nov. } 2 \\
\text { 1941, May } 17 \\
\text { 1939, Feb. } 3\end{array}$ & $\begin{array}{l}\text { Kermadec Is.. } \\
\text { Kermadec Is.. } \\
\text { Tonga Is..... } \\
\text { New Hebrides } \\
\text { Solomon Is.... }\end{array}$ & $\begin{array}{l}7.0 \\
7.1 \\
6.9 \\
7.4 \\
7.0\end{array}$ & $\begin{array}{l}84 \\
84 \\
75 \\
82 \\
90\end{array}$ & $\begin{array}{l}-1 \\
+3 \\
-3 \\
-1 \\
+4\end{array}$ & $\begin{array}{l}-2 \\
+2 \\
-2 \\
-2 \\
0\end{array}$ & $\begin{array}{l}-2 \\
+3 \\
-4 \\
-1 \\
+4\end{array}$ & $\begin{array}{r}-2 \\
-1 \\
-3 \\
0 \\
+2\end{array}$ & $\begin{array}{r}-3 \\
+2 \\
-4 \\
0 \\
+2\end{array}$ & $\begin{array}{r}-1 \\
0 \\
-3 \\
? \\
-1\end{array}$ & $\begin{array}{r}0 \\
+1 \\
-3 \\
-2 \\
-4\end{array}$ & $\begin{array}{l}-2 \\
+1 \\
-3 \\
-1 \\
+1\end{array}$ \\
\hline $\begin{array}{l}26 \\
27 \\
28 \\
29 \\
30\end{array}$ & $\begin{array}{ll}\text { 1939, Apr. } & 30 \\
\text { 1939, Jan. } & 30 \\
\text { 1938, May } 12 \\
\text { 1941, Jan. } 13 \\
\text { 1942, Jan. } 27\end{array}$ & $\begin{array}{l}\text { Solomon Is... } \\
\text { Solomon Is.... } \\
\text { New Guinea.. } \\
\text { Off N. Guinea } \\
\text { New Guinea. }\end{array}$ & $\begin{array}{l}7.9 \\
7.9 \\
7.5 \\
7.1 \\
7.1\end{array}$ & $\begin{array}{r}90 \\
90 \\
97 \\
92 \\
106\end{array}$ & $\begin{array}{l}+6 \\
-2 \\
+1 \\
+2 \\
-4\end{array}$ & $\begin{array}{l}+6 \\
-1 \\
-1 \\
+1 \\
-4\end{array}$ & $\begin{array}{r}+6 \\
-2 \\
? \\
+3 \\
-4\end{array}$ & $\begin{array}{r}+2 \\
-2 \\
? \\
+1 \\
-3\end{array}$ & $\begin{array}{r}+6 \\
? \\
0 \\
+3 \\
-4\end{array}$ & $\begin{array}{l}+2 \\
+1 \\
+1 \\
-2 \\
-2\end{array}$ & $\begin{array}{r}+3 \\
-1 \\
0 \\
-2 \\
-2\end{array}$ & $\begin{array}{r}+4 \\
-1 \\
0 \\
+1 \\
-3\end{array}$ \\
\hline $\begin{array}{l}31 \\
32 \\
33 \\
34 \\
35\end{array}$ & $\begin{array}{l}\text { 1940, Apr. } 1 \\
\text { 1938, Feb. } 1 \\
\text { 1941, Sept. } 12 \\
\text { 1942, June } 18 \\
\text { 1938, Oct. } 10\end{array}$ & $\begin{array}{l}\text { New Guinea } \\
\text { New Guinea } \\
\text { New Guinea } \\
\text { Caroline Is.. } \\
\text { Celebes.... }\end{array}$ & $\begin{array}{l}6.8 \\
8.2 \\
7.0 \\
7.1 \\
7.3\end{array}$ & $\begin{array}{r}102 \\
110 \\
107 \\
94 \\
109\end{array}$ & $\begin{array}{r}-1 \\
+1 \\
0 \\
-2 \\
-3\end{array}$ & $\begin{array}{r}-1 \\
+1 \\
0 \\
0 \\
-2\end{array}$ & $\begin{array}{l}-1 \\
+-1 \\
-3 \\
-4 \\
-3\end{array}$ & $\begin{array}{r}0 \\
+4 \\
-1 \\
-3 \\
-4\end{array}$ & $\begin{array}{l}-1 \\
+1 \\
-4 \\
-4 \\
-5\end{array}$ & $\begin{array}{l}-1 \\
-1 \\
-1 \\
-1 \\
-3\end{array}$ & $\begin{array}{l}-1 \\
+1 \\
-2 \\
-2 \\
-4\end{array}$ & $\begin{array}{l}-1 \\
+1 \\
-2 \\
-2 \\
-3\end{array}$ \\
\hline $\begin{array}{l}36 \\
37 \\
38 \\
39 \\
40\end{array}$ & $\begin{array}{l}\text { 1941, Nov. } 8 \\
1942, \text { Oct. } 20 \\
1942 \text {, Apr. } 8 \\
1938, \text { June } 16 \\
1938 \text {, Nov. } 5,8^{\mathbf{h}}\end{array}$ & $\begin{array}{l}\text { Celebes....... } \\
\text { Philippine Is. } \\
\text { Philippine Is. } \\
\text { Riu-Kiu Is... } \\
\text { Japan....... }\end{array}$ & $\begin{array}{l}7.1 \\
7.1 \\
7.6 \\
7.3 \\
7.7\end{array}$ & $\begin{array}{r}114 \\
108 \\
106 \\
90 \\
77\end{array}$ & $\begin{array}{l}-2 \\
-3 \\
-3 \\
-5 \\
-8\end{array}$ & $\begin{array}{r}-2 \\
-3 \\
0 \\
-4 \\
-5\end{array}$ & $\begin{array}{l}-2 \\
-2 \\
-3 \\
-6 \\
-5\end{array}$ & $\begin{array}{l}-2 \\
-3 \\
-2 \\
-8 \\
-7\end{array}$ & $\begin{array}{l}-3 \\
-2 \\
-3 \\
-6 \\
-3\end{array}$ & $\begin{array}{r}-2 \\
0 \\
-3 \\
-5 \\
-8\end{array}$ & $\begin{array}{l}-1 \\
-2 \\
-5 \\
-5 \\
-7\end{array}$ & $\begin{array}{l}-2 \\
-2 \\
-3 \\
-6 \\
-6\end{array}$ \\
\hline $\begin{array}{l}41 \\
42 \\
43 \\
44 \\
45\end{array}$ & $\begin{array}{l}\text { 1938, Nov. } 5,10^{\mathrm{h}} \\
1938 \text {, Nov. } 6 \\
1938 \text {, June } 10 \\
1941 \text {, Nov. } 18 \\
\text { 1939, May } 1\end{array}$ & $\begin{array}{l}\text { Japan...... } \\
\text { Japan..... }\end{array}$ & $\begin{array}{l}7.7 \\
7.6 \\
7.6 \\
7.7 \\
7.0\end{array}$ & $\begin{array}{l}78 \\
77 \\
95 \\
87 \\
75\end{array}$ & $\begin{array}{l}-7 \\
+1 \\
-8 \\
-7 \\
-5\end{array}$ & $\begin{array}{l}-5 \\
+1 \\
-7 \\
-7 \\
-5\end{array}$ & $\begin{array}{r}-7 \\
0 \\
-10 \\
-8 \\
-3\end{array}$ & $\begin{array}{l}-6 \\
+-1 \\
-8 \\
-8 \\
-6\end{array}$ & $\begin{array}{l}-2 \\
+4 \\
-11 \\
-9 \\
-4\end{array}$ & $\begin{array}{l}-7 \\
+1 \\
-7 \\
-9 \\
-3\end{array}$ & $\begin{array}{l}-7 \\
+2 \\
-6 \\
-7 \\
-5\end{array}$ & $\begin{array}{l}-6 \\
+2 \\
-8 \\
-8 \\
-5\end{array}$ \\
\hline $\begin{array}{l}46 \\
47 \\
48 \\
49 \\
50\end{array}$ & $\begin{array}{l}\text { 1940, Aug. } 1 \\
\text { 1940, Aug. } 22 \\
1938 \text {, Nov. } 17 \\
\text { 1938, Nov. } 10 \\
\text { 1941, June } 26\end{array}$ & $\begin{array}{l}\text { W. Alaska.... } \\
\text { W. Alaska.... } \\
\text { Andaman Is... }\end{array}$ & $\begin{array}{l}7.4 \\
7.0 \\
7.3 \\
8.2 \\
7.7\end{array}$ & $\begin{array}{r}76 \\
37 \\
33 \\
35 \\
124\end{array}$ & $\begin{array}{r}+4 \\
0 \\
+2 \\
-2\end{array}$ & $\begin{array}{r}+4 \\
+1 \\
0 \\
-2\end{array}$ & $\begin{array}{r}+1 \\
+4 \\
0 \\
+2 \\
+1\end{array}$ & $\begin{array}{r}0 \\
+3 \\
0 \\
+1 \\
+1\end{array}$ & $\begin{array}{r}0 \\
+7 \\
-1 \\
+2 \\
-1\end{array}$ & $\begin{array}{r}+1 \\
+4 \\
-1 \\
+1 \\
0\end{array}$ & $\begin{array}{r}0 \\
+3 \\
-1 \\
+1 \\
-1\end{array}$ & $\begin{array}{r}0 \\
+4 \\
0 \\
+1 \\
0\end{array}$ \\
\hline $\begin{array}{l}51 \\
52\end{array}$ & $\begin{array}{l}\text { 1941, Feb. } 9 \\
\text { 1939, July } 18\end{array}$ & $\begin{array}{l}\text { Off Eureka, } \\
\text { Cal.......... } \\
\text { Off Vancouver } \\
\text { Is.......... }\end{array}$ & $\begin{array}{l}6.7 \\
6.5\end{array}$ & $\begin{array}{r}81 / 2 \\
17\end{array}$ & -2 & 1 & $\begin{array}{l}-2 \\
+2\end{array}$ & $\begin{array}{l}-1 \\
+1\end{array}$ & $\begin{array}{l}+1 \\
+1\end{array}$ & $\begin{array}{l}-1 \\
+2\end{array}$ & $\begin{array}{l}+3 \\
+3\end{array}$ & $\begin{array}{r}0 \\
-1\end{array}$ \\
\hline
\end{tabular}


focal depth (and the corresponding increase in $B$ ) may be given either by a trigonometric function or by an exponential function (depending on the change of wave velocity with depth), so long as the focus remains above the Mohorovicic discontinuity. For waves with periods of about 20 seconds used in this paper the first alternative seems to be the more likely one. Combining all results available, it seems that for shocks with a depth of focus of about $35 \mathrm{~km} .0 .1$ should be added to the magnitude calculated from (1) to bring the resulting $M$ into agreement with the original zero point of Richter's scale, and that the values given in table 4 are not

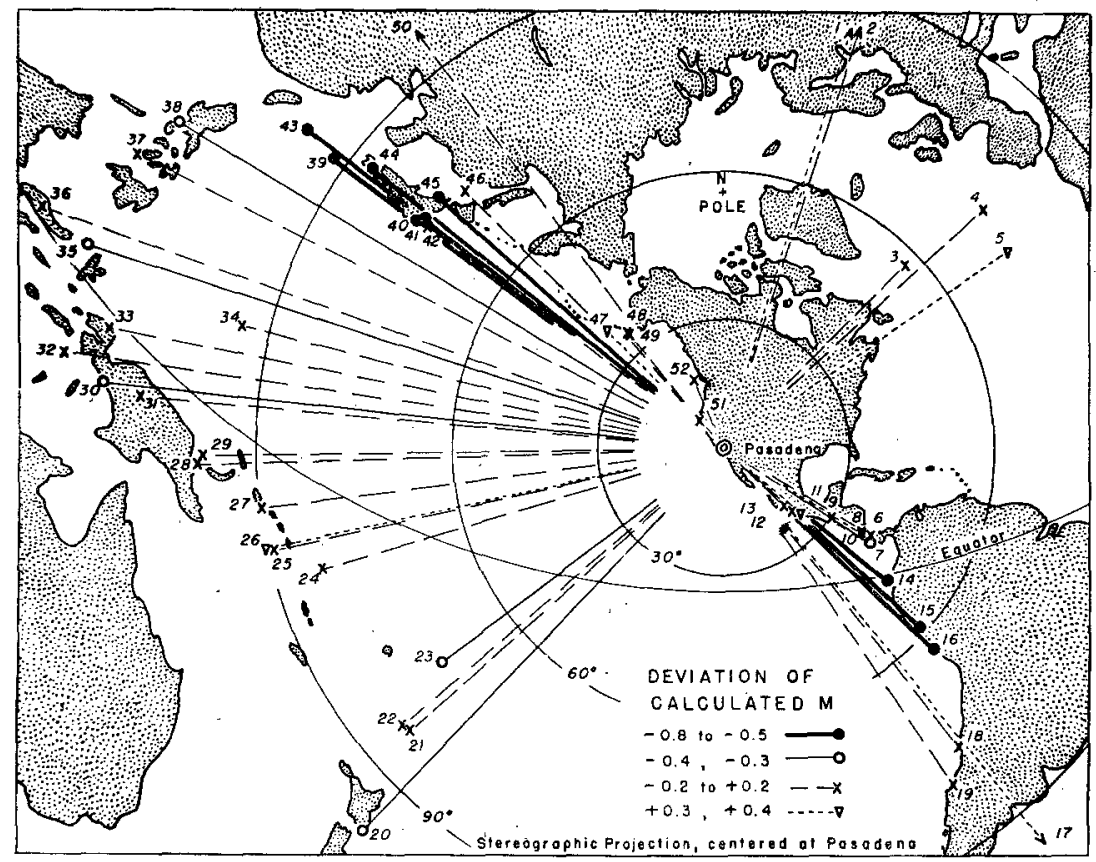

Fig. 1. Paths of surface waves from shocks numbered 1 to 52 in table 6 , with indication of deviation of $M$ as calculated from records of surface waves in southern California. The figure was drawn by Mr. John M. Nordquist.

affected by more than \pm 0.2 by variations in focal depth so long as this does not exceed $40 \mathrm{~km}$.*

The distribution of the original energy in azimuth can be found only by a study of each individual shock. Finally, the effect of loss of energy due to absorption along the wave path and to the effect of changes in velocity along the path may be studied by investigating the amplitudes arriving from different earthquake foci at a given station. For this purpose 52 shocks were selected (table 6), their magnitudes determined by using data from stations outside of California and equation (1) with tables 1 and 4 ; the maximum trace amplitudes of the records were measured on the standard torsion seismograms of the stations of the Pasadena group; from these, $M$ was redetermined without using the (unknown) value of $C$. It was evident imme-

* Note added in proof: A paper assigning magnitudes to deep-focus earthquakes is in course of publication. 
diately that nine shocks gave a magnitude of 0.5 or more too small at all stations. These were temporarily omitted, and the average remaining residuals for each station were taken to serve as station correction $C$. These are given in the last section of table 1 . The value for Pasadena $(+0.08)$ agrees well with the value +0.05 given in the first section of table 1 from routine measurements for other shocks. All calculated values of $C$ would have been about 0.1 unit greater if all shocks, including those with relatively too small surface waves, had been used in their determination.

Equation (1) can now be used again to calculate $M$ from records of each southern California station, but including now the individual values of $C$. Its deviations from the average for the shocks based on amplitudes reported from stations in other regions are tabulated in table 6 . All calculations were carried out to two decimals, but only one is given in table 6 . The last column shows the mean deviations for the southern California stations. The largest standard error of the mean, for shock no. 25 , is 0.11 units of $M$; all others are smaller than 0.1 . However, this does not include systematic errors which may be due to the method and may also include the error in the determination of $C$.

Figure 1 shows the paths of the surface waves of the 52 shocks. Four groups of the mean deviations given in the last column of table 6 are indicated by different symbols. The paths along which the surface waves lose so much energy that the calculated magnitude of the shocks is half a magnitude or more too small fall in two very narrow belts. For a rather large fraction of its length one follows the boundary of the Pacific Basin near the Japanese and Aleutian Islands, the other its boundary in the region of Central America. This result agrees with previous findings that surface waves traveling for a similar distance along the western boundary of the Pacific Basin were unusually small. Frequently, two distinct trains of surface waves are recorded in such instances, one traveling with the velocities characteristic for surface waves along Pacific paths, a later one with those usually found for surface waves propagated across continents. For this and other reasons there is little doubt that the loss of energy along the paths mentioned is due to reflection and diffraction of energy along the part of the path which crosses and recrosses repeatedly the discontinuity between the Pacific and the continental structure. Thus far, no indication has been found of a similar loss in energy for the $G$ waves which have wave lengths of several hundred kilometers, much in excess of the probable maximum depth at which there is a distinct difference in elastic constants and density between the material below the Pacific Basin and the surrounding continents.

It is difficult to use a numerical factor to introduce this loss of energy just discussed. Usually, it has been combined with the absorption factor $k$. Thus, for transpacific paths this came out higher than for transcontinental paths, and still higher for paths with repeated crossing of the Pacific boundary. The few data with pure Pacific paths do not indicate a larger absorption there. The combination of both phenomena in the calculation of $k$ has the disadvantage that the loss by reflection and diffraction of the energy at the Pacific boundary is distributed over the whole path; thus an effect of epicentral distance is introduced into the calculation which is not justified. Equation (3) shows that the effect corresponding to a deviation $d$ in $M$, if distributed over the distance $\Delta$ in degrees is given approximately by $-24 k \Delta$; this gives about $-2000 \%$ if $\Delta$ is near $80^{\circ}$. Considering that $k=0.0003$ 
was assumed in the calculations, the following values of $k$ result if at a distance of about $80^{\circ}$ a deviation $d$ in $M$ is found:

\begin{tabular}{lrcrrr} 
Deviation $d \ldots \ldots \ldots$ & \multicolumn{1}{c}{+0.2} & 0.0 & \multicolumn{1}{c}{-0.2} & \multicolumn{1}{c}{-0.4} & \multicolumn{1}{c}{-0.8} \\
Deviation of $k \ldots \ldots$ & -0.0001 & 0.0000 & +0.0001 & +0.0002 & +0.0004 per km. \\
$k$ calculated $\ldots \ldots \ldots$ & 0.0002 & 0.0003 & 0.0004 & 0.0005 & 0.0007 per $\mathrm{km}$.
\end{tabular}

Thus, for surface waves along the critical paths to southern California the calculated values of $k$, supposing that the small amplitudes are due to absorption, would be about 0.0006 per $\mathrm{km}$. This agrees well with the figures found previously for paths along the western boundary of the Pacific Basin.

The first five shocks of table 6, with paths across continents and the Atlantic Ocean, have prevailingly positive deviations as indicated by the relatively too large amplitudes of surface waves in southern California. If the mean deviation of +0.14 for shocks numbered 1 to 5 were correct, the preceding table would give about $k=0.0002$ as compared with the average of 0.00016 found previously for such paths. The agreement is good considering the possible errors, especially the fact that the result depends to a considerable extent on the absolute value of the station corrections $C$. Similar results are found for the paths from Guatemala and Mexico. Moreover, these show that the negative residuals for shocks numbered 14 to 16 are not due to this section of their paths.

For the large majority of the transpacific paths (nos. 18-38) slightly too small amplitudes are recorded in southern California, but this may well be due to a small error in $C$ as mentioned above. Otherwise, the average deviation of about -0.1 in $M$ would correspond to about $k=0.00035$.

A peculiar exception from the large negative residuals for shocks in southern Japan is indicated in shock 42 . This was an aftershock of nos. 40 and 41 with only slightly different epicenter. While most stations of the world reported more or less the same amplitudes for all three shocks, with rather slightly less for the third, its amplitudes at all stations of the California group were almost five times larger than those of the first and second. Possibly, here is an instance of different distribution in azimuth of the energy radiated at the source.

Thus, figure 1 shows that for shocks with surface waves arriving in southern California along the critical azimuths, for example from southern Japan and from Ecuador-Peru, at least 0.5 should be added to the calculated magnitude. If the surface waves have crossed the Pacific Basin without being tangent to its boundary, 0.1 or 0.2 should be added; for shocks with paths completely outside the Pacific Basin, 0.1 or 0.2 should be subtracted. For other stations, special research is needed to find the corresponding corrections.

Summary.-A study of amplitudes of surface waves having periods of about 20 seconds is employed to improve the calculation of magnitudes of distant shallow earthquakes. Table 3 gives station corrections; table 4 , revised figures for the effect of epicentral distance. It is found that for epicentral distances between about $20^{\circ}$ and $175^{\circ}$ the average observed amplitudes correspond closely to those calculated with an absorption coefficient $k=0.0003 \mathrm{per} \mathrm{km}$. For paths completely outside or inside the Pacific Basin, $k=0.0002 \pm$ per $\mathrm{km}$., while for paths tangent to its boundary the amplitudes of surface waves with periods of about 20 seconds may be re- 
duced by two-thirds or more (in extreme cases by almost nine-tenths) through reflection or refraction of energy; such seismograms of shallow shocks may be taken as indicating intermediate depth of focus.

\section{REFERENCES}

B. Gutenbere, Handbuch der Geophysit, Vol, 4, Berlin (1932).

B. Gutenberg and C. F. Richter, "On Seismic Waves (third paper), Gerlands Beitr. z. Geophysik, 47:73-131 (1936).

C. F. Richter, "An Instrumental Earthquake Magnitude Scale," Bull. Seism. Soc. Am., $25: 1-32(1935)$.

California Institute of Technology

Pasadena, California

(Baloh Gradtate Sohoot of the Geologioal Sciences, Contribution No, 372) 